HUNGARIAN AGRICULTURAL ENGINEERING

$N^{\circ} 37 / 2020$ 5-13

Published online: http://hae-journals.org/

HU ISSN 0864-7410 (Print) / HU ISSN 2415-9751(Online)

DOI: 10.17676/HAE.2020.37.5

Received: 10.11.2019 - Accepted: 10.02.2020
PERIODICAL OF THE COMITTEE OF

AGRICULTURAL AND BIOSYSTEM

ENGINEERING OF

THE HUNGARIAN ACADEMY OF SCIENCES

and

SZENT ISTVÁN UNIVERSITY

Faculty of Mechanical Engineering

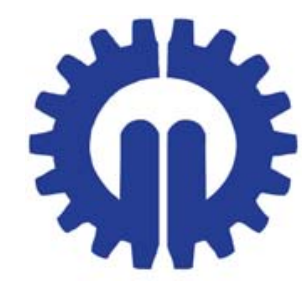

\title{
SMALL AND MEDIUM-SIZED ENTERPRISES WITHIN THE CIRCULAR ECONOMY: CHALLENGES AND OPPORTUNUTIES
}

\author{
Author(s): \\ Doğuş BİNEK, Khawla AL-MUHANNADI
}

\section{Affiliation:}

Szent István University, 2100 Gödöllö, Páter Károly u. 1

\section{Email address:}

Binek.Dogus@hallgato.uni-szie.hu, khawla.almuhannadi@gmail.com

Abstract: Small and Medium Enterprises (SMEs) are playing a vital role in most economies and they are key to the successful adoption of the circular economy, one where many materials are re-circulated, recycled, and re-used. This study aims to understand the concept of a circular economy and increase knowledge about the challenges and opportunities of the implementing circular economy for SMEs through a systematic literature review. For his study, Google Scholar, Web of Science, Research Gate and Science Direct databases have been used. The study concludes that SMEs often lack knowledge about opportunities of circular economy and their main priority is on their core business operation. We need a powerful government agenda, supported programs by policymakers who understand issues faced by SMEs and encourage them to think and act differently.

Keywords: Circular economy, SMEs, sustainability, green SMEs

\section{Introduction}

The interest towards the Circular Economy (CE) concept gains growing popularity among the academics, consumers, producers and small and medium-sized enterprises (SMEs). The circular economy concept was first introduced at the end of the last century. The first scientific papers on the topic were published in the 1980s. After that, it received increasing attention from scholars (Lieder \& Rashid, 2016). Many definitions could be found in literature around harmonizing economic growth and environmental protection. The circular economy has been described as an industrial economy that relies on the "restorative capacity of natural resources" (Bastein et al., 2013) and aims to eliminate or at least minimize waste, utilize renewable sources of energy gradual ending the use of harmful substances (MacArthur, 2012). The circular economy is also defined as "an economic system that represents a change of paradigm in the way that human society is interrelated with nature and aims to prevent the depletion of resources, close energy and materials loops, and facilitate sustainable development" (Ormazabal et al., 2018). Accordion to Schulte (2003), "Circular economy is not just concerned with the reduction of the use of the environment as a sink for residuals but rather with the creation of self-sustaining production systems in which materials are used over and over again." According to Rizos et al. (2016 ), more SMEs are showing interest in the circular economy because it's closing loops and provides resource efficiency. Saving on material costs, creating competitive advantage and gaining opening ways for new markets are other reasons SMEs are interested in the circular economy. Countries like China, Germany, UK, France and Japan have advanced in the development of policies for the circular economy (Blomsma and Brenan, 2017; Murray et al., 2017). In this way, the circular economy Package launched by the European Commission in 2015 and the EU's contribution of about 119.5 euro million for Circular Economy proposals (European Commission, 2016) is one of the most significant incentives that guide the actions of European countries and companies towards the implementation of the Circular Economy (Gordeeva, 2017).

Small and medium enterprises (SMEs) should have the most important influence in this process because they make up $95 \%$ of companies in OECD member countries (OECD, 2017). In the SME definition of European Union (EU) enforced on 1 January 2005 (OECD, 2005) an "independence" dimension, together 
with the criteria of annual turnover and number of employees are stated, where an independent SME is described as "the one where $25 \%$ or more of the enterprise's capital (or equity) is not undertaken by an enterprise or that its capital is not owned by enterprises that are not defined as SMEs" (Yurttadur and Kaya, 2012).

For the enterprises that comply with the independence criterion, the quantitative factors which determine whether a company is an SME or not are, employee number and sales turnover or balance sheet total, as illustrated in Table 1.

Table 1. Quantitative categorization of SMEs in the European Union

Source: Muller et.al., 2014.

\begin{tabular}{|l|l|l|l|}
\hline & $\begin{array}{l}\text { Mikro- } \\
\text { Sized } \\
\text { SME }\end{array}$ & $\begin{array}{l}\text { Small- } \\
\text { Sized } \\
\text { SME }\end{array}$ & $\begin{array}{l}\text { Medium- } \\
\text { Sized SME }\end{array}$ \\
\hline $\begin{array}{l}\text { Number of } \\
\text { employees }\end{array}$ & $<10$ & $<50$ & $<250$ \\
\hline Turnover & $\begin{array}{l}\leq \text { EUR 2 } \\
\text { million }\end{array}$ & $\begin{array}{l}\leq \text { EUR10 } \\
\text { million }\end{array}$ & $\begin{array}{l}\leq \text { EUR 50 } \\
\text { million }\end{array}$ \\
\hline $\begin{array}{l}\text { Balance } \\
\text { sheet total }\end{array}$ & $\begin{array}{l}\leq \text { EUR 2 } \\
\text { million }\end{array}$ & $\begin{array}{l}\leq \text { EUR } \\
10 \text { EUR 43 } \\
\text { million }\end{array}$ & $\begin{array}{l}\leq \text { Eillion } \\
\text { mion }\end{array}$ \\
\hline
\end{tabular}

First, based on analysis of current literature, circular economy concept and SMEs introduced. After introducing the methodology, circular economy challenges and opportunities for SMEs discussed. This paper aimed to address the following research questions:

1. Which are the main challenges of Circular Economy implementation in SMEs?

2. Which are the main opportunities of Circular Economy implementation in SMEs?

3. What is the impact of the circular economy on SMEs?

\section{Methodology}

In this literature review, we used a systematic research method. Cook et al., (1997) state that "Systematic reviews differ from traditional narrative reviews by adopting a replicable, scientific and transparent process, in other words, a detailed technology that aims to minimize bias through exhaustive literature searches of published and unpublished studies and by providing an audit trail of the reviewer's decisions, procedures and conclusions."

Table 2. The scope of the literature review

\begin{tabular}{|l|l|}
\hline Criterion & Included \\
\hline $\begin{array}{l}\text { Scope for the } \\
\text { search }\end{array}$ & $\begin{array}{l}\text { Google Scholar, Research } \\
\text { Gate, Web of Science, } \\
\text { Science Direct }\end{array}$ \\
\hline Source & $\begin{array}{l}\text { Peer-reviewed journal } \\
\text { articles }\end{array}$ \\
\hline $\begin{array}{l}\text { Search } \\
\text { parameters }\end{array}$ & $\begin{array}{l}\text { Keywords appearing in the } \\
\text { title }\end{array}$ \\
\hline Language & English \\
\hline Period & All years to present \\
\hline & $\begin{array}{l}\text { Literature focusing on } \\
\text { frameworks to enable a } \\
\text { circular economy in SMEs }\end{array}$ \\
\hline
\end{tabular}


Accordion to Tranfield et al., (2003) "A systematic search begins with the identification of keywords and search terms, which are built from the scoping study, the literature and discussions within the review team. The reviewer should then decide on the search strings that are most appropriate for the study. The search strategy should be reported in detail sufficient to ensure that the search could be replicated".

For the purpose of this study, a systematic literature review on the approach towards CE of SMEs, a computer search of the Google Scholar, Web of Science, Science Direct and Research Gate databases on the literature available on Circular Economy and SMEs has been conducted. Data collection consisted of searching the keywords "circular economy", "SMEs", "sustainability", "green SMEs" and all the combinations of them. After analysis of the existing articles, 41 papers considered coherent for the purpose of this study.

\section{SMEs Within The Circular Economy}

Small and medium-sized enterprises (SMEs) are increasingly aware of the benefits of closing loops and improving resource efficiency: saving material costs, creating competitive advantages and new markets are among the main reasons for European SMEs to take action. From the SMEs surveyed, more than two-thirds are satisfied with the return on their investments in resource efficiency improvements; more than one-third of the SMEs have experienced reductions in their production costs in the past two years (European Commission, 2013). For instance, by implementing a certified Environmental Management System (EMS), two-thirds of SMEs surveyed in a U.K. Defra study found their sales increased by $£ 14,961$ on average per million turnovers per year ( Ruth \& Burr, 2011). However, as explained, it is not always easy for SMEs to reap the benefits of more circular approaches. SMEs account for $99 \%$ of all European businesses and generate two-thirds of the jobs in Europe (OECD, 2010), yet their involvement in the circular economy remains limited as their activities are typically determined by large firms they provide for in supply chains (Klewitz \& Hansen, 2014; Ormazabal et al., 2016).

Implementing the Circular Economy in SMEs requires that multiple challenges be overcome; A considerable amount of literature has been published on the challenges that SMEs face to implement the Circular Economy. According to Rizos et al. (2015), the main barriers for an SME taking up Circular Economy initiatives are financial support and resources, in terms of skills and knowledge. Rizos et al.(2015) state that "policy-makers need to first better understand the complex challenges faced by SMEs to develop appropriate supportive policy frameworks." Accordion to Lieder and Rashid (2016), "essential activities for successful CE implementation, such as business models, product design, supply chain design and choice of material are in control and hence finally determined by manufacturing companies with the underlying motivation of gaining economic benefits. In this scenario, it is obvious that a transition towards the CE will not appear favorable for manufacturing companies since it will be perceived as a constraint to industrial activities rather than an opportunity for sustainable business and growth." Law and Gunasekaran (2007) state that "Management mindset thus plays an important role in the sustainability strategy adoption." It is clear that for an SME working towards a Circular Economy, those individual mindsets, the way an individual thinks and behaves, is playing an important role in supporting the transition. Ghenţa \& Matei (2018), however, note that the impact of SMEs on the environment is less investigated, although SMEs impact on job creation, innovation, social stability, and growth is recognized.

Lack of support from suppliers and demand network highly recognized as a challenge in the existing literature (Meqdadi, 2012; Rizos et al., 2016). Customers' purchasing decisions are partially affected by sustainability standards. Therefore, their fulfillment is not typically considered a high priority (Wycherley, 1999). Additionally. SMEs have a low impact on engagement of their suppliers (Zhu, 2008).

In a recent study done in Pakistan, Agyemang et al. (2018), flags the deficiency in researching barriers in emerging and developing countries besides China. The study highlights unawareness; cost and financial constraints and lack of expertise are the top barriers for adopting CE in Pakistan. The unawareness of CE includes the inability to understand the incentives for the incorporation of $\mathrm{CE}$ in their operations. Lack of expertise and comprehensive technical know-how was among the main concerns raised by the sample of the study. The study also noted the perception among participants in the study, that shifting to CE would mean losing a decay of investment prior knowledge of CE, and a costly new initial investment for the shift. Lack of 
technical and technological capacity and the ability to embrace CE practices appears as an important barrier. Another barrier to CE implementation was noted as the lack of supply chain integration and supply chain complexity.

Transforming current linear business models would require new technologies and sustainable production to be integrated into business-as-usual operations, and competent experts who can manage them. However, the demand for environmentally friendly technologies is generally quite low and technical capacities are insufficient. Lack of technical know-how may result in adopting linear business models and technologies by SMEs and they are depending on their suppliers' suggestions for innovative technical solutions (Rizos et al., 2016). Other factors that may prevent the adoption of a Circular Economy approach by SMEs as an insufficient investment in technologies focusing on circular product designs and operations, lack of advanced resource efficiency technologies and low pricing signals of raw materials. (Eijk, 2015).

Although there is significant heterogeneity among SMEs in different sectors, their responses and their capacity to receive a "green solution" are generally similar in terms of organization and management regime. The managers of SMEs are usually also the owner of the firm and thus has significant power on the strategic decisions of the company. As such, some SME managers may have a positive attitude towards green business, while others may not. This divergence of views towards 'green business' has been attributed to several reasons in the current literature. SME are generally willing to take 'green' measures and their attitude towards green policies also depends on the sector in which they operate (Bradford \& Fraser, 2007).

Given the significance of the financial challenge and suitable sources of funding could be essential for SMEs seeking to improve their sustainability performance and introduce innovation. Studies indicate, however, that the smaller a company is the more difficult it is to understand and assess different funding options, such as EU support programs and government grants, mainly due to staff and management restrictions (Hoevenagel et al., 2007; Müller \& Tunçer, 2013). When is the time comes to bank financing, SMEs, and especially very young small businesses, face problems in obtaining the collateral or guarantees required by the banks, which often consider SME financing a risky business (Hyz, 2011; Müller and Tunçer, 2013).

Caldera et al., (2019) state that the main barriers for SMEs for implementation of Circular Economy come from the high risk due to the size of the enterprise, as many lacks of financial support for their survival, in addition to their lack of risk management plans. This is accompanied by high-cost requirements for the shift to $\mathrm{CE}$, and lack of supporting funds for a sustainable shift, or the unawareness of their existence. The lack of government support legislation (through the provision of funding opportunities, laws and regulations, effective taxation policy, etc.) is broadly recognized as an enormous barrier to the uptake of environmental investments. The absence of a concrete, consistent and strict legal framework prevents SMEs from thinking about greening their business. For example, in EU waste legislation there is no coherent definition or classification of waste materials (e.g., to distinguish waste from by product materials used for recycling), thus inducing limitations on cross-border transportation of waste (Rizos et. Al., 2015).

From the economic perspective, Circular Economy is seen to provide opportunities for cost savings, e.g. by reducing waste and energy costs. Circular Economy provides possibilities for new value creation, business growth and increases in margin and profits.

From the organizational perspective, by following CE principles companies may be able to achieve brand benefits, protect and strengthen their image and enable differentiation (Tura et al., 2019). Cost reduction and expected profitability, according to Egyemag et al. (2018), market share benefit and receiving appreciation for taking eco-business principles are listed among the top drivers to adopt $\mathrm{CE}$, among the automobiles industry in Pakistan.

The participants of the study also noted that consumers in Pakistan showing an increasing interest in circular products, and if this interest became strong and form a market demand, then even market-driven firms with no green interest, will shift to CE. The shift was also found aiming "to identify the new source to increase quality market share and subsequently higher profit" (Egyemag et al., 2018).

New technologies not only find cleaner solutions for the future but also help prevent and overcome problems caused by existing technologies. Information sharing platforms collaborate with many stakeholders and lead to better information transparency, thereby helping to adopt Circular Economy business models (MacArthur, 2013). 
The increase in prestige is due to the effective communication of the sustainable strategies of the firms. Increasing prestige improves relationships with consumers and their market share (Ormazabal and Puga-Leal, 2016).

Table 3. CE Challenges For SMEs

Source: Prepared by the authors based on the systematic literature review.

\begin{tabular}{|c|c|c|c|}
\hline Challenges & References & Opportunities & References \\
\hline $\begin{array}{l}\text { The lack of } \\
\text { capital/financial } \\
\text { support/resources }\end{array}$ & $\begin{array}{l}\text { Hoevenagel et al., 2007; } \\
\text { Rademakers et al., 2011; } \\
\text { Geng \& Doberstein, 2008; } \\
\text { Shi et al., 2008; Ormazabal } \\
\text { et al., 2016; Rizos et al., } \\
\text { 2015; Caldera et al., 2019; } \\
\text { Müller \& Tuncer, 2013; Hyz, } \\
\text { 2011. }\end{array}$ & $\begin{array}{l}\text { Sustainability of the } \\
\text { enterprise }\end{array}$ & $\begin{array}{l}\text { Moore } \\
\& \\
\text { Morni } \\
\text { ng, } \\
2009 \text {; } \\
\text { Noci } \\
\& \text { Verg } \\
\text { anti } \\
1999 ; \\
\text { Calder } \\
\text { a et al., } \\
2019 .\end{array}$ \\
\hline $\begin{array}{l}\text { The lack of information, } \\
\text { awareness, education, } \\
\text { expertise \& technical } \\
\text { skills }\end{array}$ & $\begin{array}{l}\text { Rizos et al., 2015; } \\
\text { Caldera et al., 2019; } \\
\text { Cagno et al., 2017; } \\
\text { Agyemang et al. ,2018; } \\
\text { Caldera et al., 2019. }\end{array}$ & $\begin{array}{l}\text { Cost savings from } \\
\text { reducing waste energy and } \\
\text { material and financial } \\
\text { profitability }\end{array}$ & $\begin{array}{l}\text { Tura et al., 2018, } \\
\text { Koirala, 2018; } \\
\text { Preston, 2012; } \\
\text { Ritzén \& Sandström, 2017; } \\
\text { Agyemang et al. 2018. }\end{array}$ \\
\hline $\begin{array}{l}\text { The lack of support from } \\
\text { the government }\end{array}$ & $\begin{array}{l}\text { Calogero et al., 2010; } \\
\text { Studer et al., 2006; } \\
\text { Rizos et al., 2015; } \\
\text { Hasan, 2016; } \\
\text { Agyemang et al. } 2018 ; \\
\text { Caldera et al., } 2019 \text {. }\end{array}$ & $\begin{array}{l}\text { Open collaboration and } \\
\text { communication practices }\end{array}$ & $\begin{array}{l}\text { Tura et al., 2018, } \\
\text { MacArthur, } 2013 .\end{array}$ \\
\hline $\begin{array}{l}\text { Lack of practices and } \\
\text { systems for collecting, } \\
\text { sharing and utilization }\end{array}$ & $\begin{array}{l}\text { Tura et al., 2018; } \\
\text { Caldera et al., } 2019 .\end{array}$ & $\begin{array}{l}\text { Increase of prestige, } \\
\text { adherence to national and } \\
\text { international } \\
\text { sustainability, social } \\
\text { responsibility goals }\end{array}$ & $\begin{array}{l}\text { Rizos et al., 2016; } \\
\text { Del Río et al., 2016; } \\
\text { Ormazabal \& Puga-Leal, 2016; } \\
\text { Agyemang et al. } 2018 .\end{array}$ \\
\hline Lack of clear incentives & $\begin{array}{l}\text { Tura et al., 2018; } \\
\text { Agyemang et al. 2018; } \\
\text { Caldera et al., } 2019 .\end{array}$ & $\begin{array}{l}\text { Recovery of the local } \\
\text { environment and potential } \\
\text { to create value from waste }\end{array}$ & $\begin{array}{l}\text { MacArthur, 2013; } \\
\text { Moore \& Manring, 2009; } \\
\text { Rizos et al., 2016; } \\
\text { Tura et al., 2018. }\end{array}$ \\
\hline $\begin{array}{l}\text { High initial investment } \\
\text { costs }\end{array}$ & $\begin{array}{l}\text { Tura et al., 2018, Koirala, } \\
\text { 2018; Agyemang et al., } \\
\text { 2018; Caldera et al., 2019; } \\
\text { Caldera et al., 2019. }\end{array}$ & $\begin{array}{l}\text { Improving existing } \\
\text { operations efficiency }\end{array}$ & $\begin{array}{l}\text { MacArthur, 2013; } \\
\text { Feng \& Yan, 2007; } \\
\text { Caldera et al., 2019; } \\
\text { Koirala, 2018, } \\
\text { Tura et al. }\end{array}$ \\
\hline $\begin{array}{l}\text { Incompatibility with } \\
\text { existing (linear) } \\
\text { operations }\end{array}$ & $\begin{array}{l}\text { Tura et al., 2018, } \\
\text { Agyemang et al. 2018; } \\
\text { Caldera et al., 2019; Rizos } \\
\text { et al. 2015; Tura et al., } \\
\text { 2018; Koirala, 2018. }\end{array}$ & $\begin{array}{l}\text { Supportive funds, taxation } \\
\text { and subsidy policies }\end{array}$ & $\begin{array}{l}\text { Tura et al., 2018; } \\
\text { Koirala, } 2018 .\end{array}$ \\
\hline $\begin{array}{l}\text { Lack of support from } \\
\text { supply and demand } \\
\text { network }\end{array}$ & $\begin{array}{l}\text { Rizos et al. 2015; Tura et } \\
\text { al., 2018; Agyemang et al., } \\
2018 \text {. }\end{array}$ & $\begin{array}{l}\text { Increased information } \\
\text { sharing through enhanced } \\
\text { information management } \\
\text { technologies and platforms }\end{array}$ & $\begin{array}{l}\text { Tura et al., 2018; } \\
\text { MacArthur, } 2013\end{array}$ \\
\hline $\begin{array}{l}\text { The lack of consumer } \\
\text { interest in the } \\
\text { environment or } \\
\text { uncertainty of } \\
\text { consumer's reaction } \\
\text { hinder SMEs' ability to } \\
\text { deliver inclusive growth }\end{array}$ & $\begin{array}{l}\text { Nußholz, 2017; } \\
\text { Ormazabal et al., 2016; } \\
\text { Preston, 2012; Geng and } \\
\text { Doberstein, 2008; Tura et } \\
\text { al., 2018; Koirala, 2018. }\end{array}$ & $\begin{array}{l}\text { Competitive advantage as } \\
\text { consumers seem to expect } \\
\text { higher quality sustainable } \\
\text { products }\end{array}$ & $\begin{array}{l}\text { Ormazabal et al., } 2018 \text {; } \\
\text { Caldera et al., } 2019 .\end{array}$ \\
\hline $\begin{array}{l}\text { Environmental } \\
\text { performance is not } \\
\text { considered in the } \\
\text { assessments of SME } \\
\text { funding decisions }\end{array}$ & $\begin{array}{l}\text { Koirala , 2018; } \\
\text { Caldera et al., } 2019 \text {; } \\
\text { Koirala, } 2018 .\end{array}$ & $\begin{array}{l}\text { Job creation and entering } \\
\text { new markets }\end{array}$ & $\begin{array}{l}\text { Koirala, 2018; } \\
\text { Ghența \& Matei, 2018; } \\
\text { MacArthur, 2013; } \\
\text { Moore \& Manring, } 2009 .\end{array}$ \\
\hline
\end{tabular}


MacArthur (2015) states that the implementation of Circular Economy in food, mobility and built sectors can help the environment recovery because the " $\mathrm{CO}_{2}$ emissions could drop as much as 48 percent by 2030 and 83 percent by 2050, compared with 2012 levels. Primary material consumption measured by car and construction materials, real estate land, synthetic fertilizer, pesticides, agricultural water use, fuels, and nonrenewable electricity could drop as much as 32 percent by 2030 and 53 percent by 2050 ". In addition, circular economy gives the opportunity to the companies to conquer new markets whose needs have not been met and it represents the opportunity to ensure the sustainability of the business in the long term, as it guarantees the availability and accessibility of resources in the future (Moore and Manring, 2009). Consequently, these opportunities are translated in multiple advantages: SMEs might be able to tap to or capture new markets demanding eco-products, (Moore and Manring, 2009 and Koirala, 2018) and thus increase market share and also generate efficiency gains from greening and reduce costs (Koirala, 2018). Consumers expect higher quality than sustainable products, and the creation of sustainable products can lead to the development of ecoinnovation cycles; The demand of consumers and the needs of governments and institutions can lead to the development of inventions, designs and new solutions to meet the human and nature needs of companies (Ormazabal et al., 2018).

Due to the high share of the costs associated with the consumption of energy and raw materials, the European Commission has initiated actions to closely monitor the difficulties that SMEs encounter in the process of transforming the challenges of environmental pollution into opportunities. These efforts have been materialized in an action plan through which the European Union and the Member States intend to support SMEs in exploiting the opportunities for moving to a green economy (European Commission, 2014).

A considerable amount of literature has been published on the challenges and opportunities that SMEs face to implement the CE (Table 3).

\section{Summary}

This paper reviewed literatures from different regions and different levels of development, for their understanding and application of circular economy. It was interesting to include and feel the variation in literature from the middle east, and far east, as well as Europe and the USA. The authors researched the difficulties and the opportunities facing the shift in SMEs to a circular economy, or a more sustainable policies and practices. One of the most important obstacles came from the very definition of SMEs. Because of their small size and limited budget and resources, taking a risk is not a preferred choice. Taking risk could be in using their limited resources to invest in the transition. But it can also be in a change that might not be welcomed, not to mention favored, by their supply and demand chain. Other obstacles are related to limitation in understanding circular economy and its potential. Also other important obstacles are related to lack or limitation in the know-how and technology, and also in access to funds related to circular economy adaptation and transition.

Opportunities on the other hands, lay in the potential competitive and comparative advantage an SME can gain if it started first, providing that it was a successful transition, and supported both by government's policies and by powerful market players. Funds and supporting the transition, especially from EU are available, but the challenge is in knowing how to have access to them, and benefit from what they offer. The growing consciousness among consumers and NGOs, especially now with Covid19 implications in calling for more sustainable lifestyle, can support the success of transition, and pave the road for more success, and also for more SMEs to follow their footsteps. It is the opinion of the authors, that the first SMEs who will take a calculated risk and pave the road, will gain momentum and achieve leadership and long-term gains.

\section{Conclusion}

In this study, 41 papers were examined to determine what challenges and opportunities to developing the circular economy in SMEs. In general, as the interest in the circular economy, which has gained worldwide popularity, the number of publications in this field increases. A systematic content analysis approach has been applied to increase the reliability and validity of this study. 
Implementing the CE approach in SMEs requires that numerous barriers to be overcome. SMEs often lack knowledge about circular economy business opportunities, and many SMEs do not consider 'being green' as a priority. But that doesn't mean that SMEs are against greening their business. Their main priority is on their core business operation. Greening their operations may be interesting for them if it supports their core business. That means we should use the terms like "cost reducing" when convincing them to join the circular economy. Policymakers are required who comprehend the issues and challenges faced by SMEs, policymakers who are capable and ready to influence policy support towards providing solutions for SMEs. Additionally, SME management needs reasonable and clear communication on the regional level in order to know what the problems could be and where to turn to solve these problems.

SMEs can be the main drivers of macroeconomic development towards a circular economy, but challenges and knowledge gaps, and strong uncertainties, often stands in the way of greening their businesses. Additionally, current macroeconomic settings such as deflation and low investments may also discourage SMEs to consider using circular economy models. We need to provide sufficient resources and networking opportunities for SMEs. So that way they can explore the benefits of circular economy opportunities themselves and for that purpose we need a powerful government agenda, various programs designed by policymakers to encourage SMEs to think and act different.

\section{References}

[1] African Journal of Business Management Available online:

https://academicjournals.org/ajbm/abstracts/abstracts/abstracts2012/25Jan/Yurttadur\%20and\%20Kaya.htm (accessed on Apr 27, 2020).

[2] Agyemang, M.; Zhu, Q.; Adzanyo, M.; Antarciuc, E.; Zhao, S. Evaluating barriers to green supply chain redesign and implementation of related practices in the West Africa cashew industry. Resources, Conservation and Recycling 2018, 136, 209-222, doi:10.1016/j.resconrec.2018.04.011.

[3] Bradford, J.; Fraser, E.D.G. Local authorities, climate change and small and medium enterprises: identifying effective policy instruments to reduce energy use and carbon emissions. Corp. Soc. Responsib. Environ. Mgmt 2008, 15, 156-172, doi:10.1002/csr.151.

[4] Britton 13, E.; Streets, rue P.C. 92400 F.B.F. editor of W.; scientist, E.B. is an A. political; teacher; Consultant, O.; mediator; Observed, S.A.W.H.; learned; taught; Missions, W. on; et al. Barriers \& Drivers towards a New Circular Economy. Sustainable Development, Economy and Democracy 2017 https://sustainabiltyseminar.wordpress.com/2017/10/30/barriers-drivers-towards-a-circular-economyliterature-review/ (accessed on Apr 27, 2020).

[5] B.Hyz, A. Small and Medium Enterprises (SMEs) in Greece - Barriers in Access to Banking Services. An Empirical Investigation. International Journal of Business and Social Science 2011, 2, 161-165. https://www.researchgate.net/publication/263655473_Small_and_Medium_Enterprises_SMEs_in_Greece_Barriers_in_Access_to_Banking_Services_An_Empirical_Investigation\#fullTextFileContent (accessed on Apr 27, 2020).

[6] Caldera, H.T.S.; Desha, C.; Dawes, L. Evaluating the enablers and barriers for successful implementation of sustainable business practice in 'lean' SMEs. Journal of Cleaner Production 2019, 218, 575-590, doi:10.1016/j.jclepro.2019.01.239.

[7] Cook, D.J. The Relation between Systematic Reviews and Practice Guidelines. Ann Intern Med 1997, 127, 210, doi:10.7326/0003-4819-127-3-199708010-00006.

[8] Circular Economy Report - Towards the Circular Economy Vol. 1 Available online:

https://www.ellenmacarthurfoundation.org/publications/towards-the-circular-economy-vol-1-an-economicand-business-rationale-for-an-accelerated-transition (accessed on Apr 27, 2020).

[9] Circular Economy Report - Growth Within Available online:

https://www.ellenmacarthurfoundation.org/publications/growth-within-a-circular-economy-vision-for-acompetitive-europe (accessed on Apr 27, 2020). 
[10] Department for Environment, F. and R.A. (Defra) Defra, UK - Science Search Available online: $\mathrm{http} / /$ sciencesearch.defra.gov.uk/Default.aspx?Menu=Menu\&Module=More\&Location=None\&Completed= 0\&ProjectID=16942 (accessed on Apr 27, 2020).

[11] Del Río, P.; Carrillo-Hermosilla, J.; Könnölä, T.; Bleda, M. RESOURCES, CAPABILITIES AND COMPETENCES FOR ECO-INNOVATION. Technological and Economic Development of Economy 2015, 22, 274-292, doi:10.3846/20294913.2015.1070301.

[12] Eijk, F. V.; Barriers \& Drivers towards a Circular Economy. Literature Review A-140315-R-Final. Naarden, The Netherlands: Acceleration, 2015,

[13] https://www.circulairondernemen.nl/uploads/e00e643951aef8adde612123e824493.pdf

[14] (accessed on Apr 27, 2020).

[15] Flash Eurobarometer 381: SMEs, resource efficiency and green markets - ecodp.common.ckan.site_title Available online: https://data.europa.eu/euodp/en/data/dataset/S1086_381 (accessed on Apr 27, 2020).

[16] Geng, Y.; Doberstein, B. Developing the circular economy in China: Challenges and opportunities for achieving "leapfrog development." International Journal of Sustainable Development \& World Ecology 2008, 15, 231-239, doi:10.3843/SusDev.15.3:6.

[17] Gordeeva, Y.M. Recent Developments in eu Environmental Policy and Legislation. JEEP 2017, 14, $233-$ 241, doi:10.1163/18760104-01402007.

[18] Hasan, M.N. Measuring and understanding the engagement of Bangladeshi SMEs with sustainable and socially responsible business practices: an ISO 26000 perspective. Social Responsibility Journal 2016, 12, 584-610, doi:10.1108/SRJ-08-2015-0125.

[19] Hoevenagel, R.; Lindblom, J.; Delgado, L.; Institute for Prospective Technological Studies Promoting environmental technologies in SMEs: barriers and measures.; Publications Office: Luxembourg, 2007; ISBN 9789279056932.

[20] Klewitz, J.; Hansen, E.G. Sustainability-oriented innovation of SMEs: a systematic review. Journal of Cleaner Production 2014, 65, 57-75, doi:10.1016/j.jclepro.2013.07.017.

[21] Lieder, M.; Asif, F.M.A.; Rashid, A.; Mihelič, A.; Kotnik, S. Towards circular economy implementation in manufacturing systems using a multi-method simulation approach to link design and business strategy. Int J Adv Manuf Technol 2017, 93, 1953-1970, doi:10.1007/s00170-017-0610-9.

[22] Marri, H.B.; Irani, Z.; Gunasekaran, A. Advance Manufacturing Technology implementation in SMEs: a framework of justification criteria. IJEB 2007, 5, 124, doi:10.1504/IJEB.2007.012969.

[23] Meqdadi, O.; Johnsen, T.; Joh, R. The Role of SME Suppliers in Implementing Sustainability. Piccola Impresa / Small Business 2012, 0, doi:10.14596/pisb.25.

[24] Moore, S.B.; Manring, S.L. Strategy development in small and medium sized enterprises for sustainability and increased value creation. Journal of Cleaner Production 2009, 17, 276-282, doi:10.1016/j.jclepro.2008.06.004.

[25] National Scientific Research Institute for Labour and Social Protection (INCSMPS); Ghenta, M.; Matei, A.; National Scientific Research Institute for Labour and Social Protection (INCSMPS) SMEs and the Circular Economy: From Policy to Difficulties Encountered During Implementation. AE 2018, 20, 294, doi: $10.24818 / \mathrm{EA} / 2018 / 48 / 294$.

[26] Noci, G.; Verganti, R. Managing 'green' product innovation in small firms. R\&D Management 1999, 29, 3-15, doi:10.1111/1467-9310.00112.

[27] Union, P.O. of the E. SMEs and the environment in the European Union : main report. Available online: http://op.europa.eu/en/publication-detail/-/publication/aa507ab8-1a2a-4bf1-86de-5a60d14a3977 (accessed on Apr 26, 2020).

[28] Ormazabal, M.; Prieto-Sandoval, V.; Jaca, C.; Santos, J. An overview of the circular economy among SMEs in the Basque country: A multiple case study. Journal of Industrial Engineering and Management 2016, 9, 1047-1058, doi:10.3926/jiem.2065.

[29] Prieto- Sandoval, V.; Ormazabal, M.; Jaca, C.; Viles, E. Key elements in assessing circular economy implementation in small and medium-sized enterprises. Business Strategy and the Environment 2018, 27, 1525-1534, doi:10.1002/bse.2210. 
[30] Rizos, V.; Behrens, A.; Kafyeke, T.; Hirschnitz-Garbers, M.; Ioannou, A.; Centre for European Policy Studies (Brussels, B. The circular economy: barriers and opportunities for SMEs; 2015; ISBN 9789461384799.

[31] Ritzén, S.; Sandström, G.Ö. Barriers to the Circular Economy - Integration of Perspectives and Domains. Procedia CIRP 2017, 64, 7-12, doi:10.1016/j.procir.2017.03.005.

[32] Sustainability: key issues; Kopnina, H., Shoreman-Ouimet, E., Eds.; Routledge: Abingdon, Oxon ; New York, NY, 2015; ISBN 9780415529853.

[33] Schouten, S.; Grootveld, M.; Bureau de Helling, W.B.G. (Utrecht) De circulaire economie: waarom productie, consumptie en groei fundamenteel anders moeten; Editie Leesmagazijn: Amsterdam, 2017; ISBN 9789491717307.

[34] SMEs, entrepreneurship and innovation; OECD, Ed.; OECD studies on SMEs and entrepreneurship; OECD: Paris, 2010; ISBN 9789264080317.

[35] Shi, H.; Peng, S.Z.; Liu, Y.; Zhong, P. Barriers to the implementation of cleaner production in Chinese SMEs: government, industry and expert stakeholders' perspectives. Journal of Cleaner Production 2008, 16, 842-852, doi:10.1016/j.jclepro.2007.05.002.

[36] Schulte, U.G. New business models for a radical change in resource efficiency. Environmental Innovation and Societal Transitions 2013, 9, 43-47, doi:10.1016/j.eist.2013.09.006.

[37] Tura, N.; Hanski, J.; Ahola, T.; Ståhle, M.; Piiparinen, S.; Valkokari, P. Unlocking circular business: A framework of barriers and drivers. Journal of Cleaner Production 2019, 212, 90-98, doi:10.1016/j.jclepro.2018.11.202.

[38] Tranfield, D.; Denyer, D.; Smart, P. Towards a Methodology for Developing Evidence-Informed Management Knowledge by Means of Systematic Review. British Journal of Management 2003, 14, 207222, doi:10.1111/1467-8551.00375.

[39] Waterstaat, M. van I. en TNO-rapport "Kansen voor de circulaire economie in Nederland" - Rapport Rijksoverheid.nl Available online: https:/www.rijksoverheid.nl/documenten/rapporten/2013/06/20/tnorapport-kansen-voor-de-circulaire-economie-in-nederland (accessed on Apr 27, 2020).

[40] Wycherley, I. Greening supply chains: the case of The Body Shop International. Business Strategy and the Environment 1999, 8, 120-127, doi:10.1002/(SICI)1099-0836(199903/04)8:2<120::AID-BSE188>3.0.CO;2-X.

[41] Zhu, Q.; Sarkis, J.; Lai, K.; Geng, Y. The role of organizational size in the adoption of green supply chain management practices in China. Corporate Social Responsibility and Environmental Management 2008, 15, 322-337, doi:10.1002/csr.173. 